\title{
From Substantive to Procedural Law: Better Approach to Equal Treatment of Chinese State-Owned and Private Enterprises
}

\author{
Jin Zhuang, Lingtao Liang \\ Law School, Sun Yat-sen University, Guangzhou, China \\ Email: zhjin@mail.sysu.edu.cn
}

How to cite this paper: Zhuang, J., \& Liang, L. T. (2021). From Substantive to Procedural Law: Better Approach to Equal Treatment of Chinese State-Owned and Private Enterprises. Chinese Studies, 10, 211-240.

https://doi.org/10.4236/chnstd.2021.104014

Received: October 28, 2021

Accepted: November 26, 2021

Published: November 29, 2021

Copyright $\odot 2021$ by author(s) and Scientific Research Publishing Inc. This work is licensed under the Creative Commons Attribution International License (CC BY 4.0).

http://creativecommons.org/licenses/by/4.0/

(c) (i) Open Access

\begin{abstract}
The institutional plight of dual discrimination' has forced Chinese private enterprises to commit crimes in order to survive, as they are treated differently from state-owned enterprises both politically and economically. In response, China's Criminal Law Amendment (XI) has enhanced the statutory penalties for crimes committed by private enterprises to make them more similar to those committed by state-owned enterprises. Chinese scholars considered this amendment as an important step forward in achieving equal treatment for Chinese private and state-owned enterprises. With the aim of exploring the appropriate approach of equal treatment of Chinese state-owned and private enterprises, we start our research by examining the above considerations. However, from the perspective of the theory of the purpose of penalties, the punishment for crimes committed by private enterprises need not be absolutely identical to those for crimes committed by state-owned enterprises. Therefore, enhancement of the penalties aiming to protect private enterprises in criminal substantive law does not contribute to realization of the principle of equality before the law. Switching from criminal substantive law to criminal procedural law is a better approach to achieve equal treatment for state-owned and private enterprises in China. The reason for this is that, according to the theory of rectificatory justice, in order to achieve equal treatment of private and state-owned enterprises, more judicial preferences should be granted to private enterprises in the criminal procedural law, rather than in the substantive law. Within the framework of the current China's criminal procedure law, we can take two parts of procedural strategies in application of procedure law into consideration, including: improvement in the application of China's corporate compliance deferred prosecution institution and restriction of custody against personnel in Chinese private enterprises.
\end{abstract}




\section{Keywords}

Equal Treatment, Chinese Private Enterprises, Criminal Substantive Law, Criminal Procedural Law

\section{Introduction}

Chinese scholars have long argued the indisputable fact that Chinese private enterprises and state-owned enterprises are not treated equally in criminal law and this unequal treatment is manifested in criminal substantive law, i.e., there are two different systems of crimes in China's Criminal Law, which protect private enterprises and state-owned enterprises respectively, but the latter always maintains significantly higher penalties than the former. The mainstream method provided by Chinese scholars for the solution is simply making the penalties of those closer together. China's Criminal Law Amendment (XI), which came into effect this year, satisfied the demands of scholars to some extent by raising the penalties for protecting private enterprises and thus making the penalties for protecting private enterprises closer to those for protecting state-owned enterprises. However, can this rigid method, really achieve equal treatment between state-owned enterprises and private enterprises? From the standpoint of this article, this is just a "meaningless big show", because it does not really strengthen the protection of private enterprises, and even forces private entrepreneurs to fall in a more difficult position. To truly improve the treatment of private enterprises in criminal law, a broader perspective, in which in the second section of main text we explore the institutional roots and criminal causes of discrimination against private enterprises in China, in the third and fourth section we propose targeted solutions to improve their legal status and in last section, we conclude our final solution, should be adopted.

In the second section of main text, we start to seek the institutional roots and criminal causes. Chinese private enterprises have fall into a tough situation over many years and are now still suffering from it, which is unequal protection of state-owned and private enterprises in China. With the wish to solve the problem, first of all, we are exploring to precisely locate and point out the realistic background of the generation of this tough situation, which constitutes second section of main text. As the result of exploration, we recognize that dual discriminatory institutional plight in China induces the inevitable crimes committed by private enterprise, therefore we need a justified and workable approach in Criminal Law for solution.

Therefore, in the third section, we will examine whether the criminal substantive law should provide equal treatment to Chinese state-owned enterprises and private enterprises. Even though China's substantive criminal law provides differentiated protection for private and state-owned enterprises, we will find that this differentiated protection of criminal substantive law is of justification, i.e., this dif- 
ferentiated protection is consistent with the principle of equality for all, by looking back at the theory of the purpose of punishment. It means that the approach of criminal substantive law is no longer able to solve the problem and thus we get a staged conclusion: looking for another better solution is a must.

That leads to the fourth section of our text. In this section, we decide to make a switch of approach from perspective of criminal substantive law to criminal procedural law and examine if it is the correct way for a better solution. We are trying to discover the jurisprudential basis of equal treatment for both stateowned and private enterprises in China's procedural law and we found it, which we consider as the theory of substantive equality under rectificatory justice. From the position of theory of substantive equality under rectificatory justice in procedural law, equal treatment can now eventually be justified. But it is not enough. The last and most important problem is what kind of workable specific methods to achieve equal treatment. For that question, under position of theory of substantive equality, we propose the two specific procedural strategies as specific methods, which consists of improvement in the application of China's corporate compliance deferred prosecution institution and restriction of custody against personnel in Chinese private enterprises.

In the final conclusion, we confirm the switch from substantive law to procedural Law is indeed a better approach to achieve equal treatment of Chinese state-owned and private enterprises.

\section{Realistic Background: The Institutional Plight of Private Enterprises and Induced Crime in China}

Chinese private enterprises have been under plight of institutional discrimination (Chen \& Wang, 2013; He et al., 2013), and crimes committed by Chinese private enterprises are in a sense products of survival in this institutional discriminatory plight (Mei \& Zhang, 2014; Zhang, 2014). For achievement of equal treatment of Chinese state-owned and private enterprises, we can firstly describe the institutional discriminatory plight and point out the Phenomenon of induced crimes of Chinese private enterprises.

\subsection{Description of Institutional Discriminatory Plight}

Under the current institution, the Chinese private economy has long been in a plight of discrimination. Relevant studies point out that in recent years, both the total numbers of cases of suspected crimes in China's private economy and the crime rate of private entrepreneurs present a rising trend (Chinese Entrepreneurial Crime Prevention Research Center, 2019). The occurrence of the above phenomenon is inseparably linked to the current discriminatory institutional plight faced by the private economy. Discriminatory treatment from different aspects of the institution aggregates and forces private entrepreneurs to engage in illegal and criminal activities based on survival pressure. In general, the discriminatory institutional plight faced by the private economy in China can be 
unfolded at two levels: political and economic.

\subsubsection{Discrimination at the Political Level as First Part of Institutional Plight}

Discrimination at the political level has forced Chinese private entrepreneurs to resort to abnormal and even criminal means to obtain political resources. The current administration-dominant institution in China brings the undesirable consequence that state-owned enterprises close to administrative power receive prior arrangements in political resources, while private enterprises far from administrative power are marginalized in the political spectrum. Both private and state-owned enterprises inherently have the need for access to political resources (Yu \& Pan, 2008). Once private enterprises are unable to obtain political resources through normal channels at the political level, their instincts for self-development and self-protection often lead to "collusion between government personnel and businessmen", "power-for-money deals" and other gray channels to achieve their goals.

In addition, the current administration-dominant institution makes the government or state-owned enterprises hold a large number of non-market public financial resources. In the absence of adequate supervision, it is easy for personnel of state organs or managers in state-owned enterprises to conduct rent-seeking, and for private enterprises to conduct bribery or other improper means of business competition, while the law-abiding private enterprises fall in the fate of elimination for the sake of "bad money to drive out good money" effect.

\subsubsection{Discrimination at the Economic Level as Second Part of Institutional Plight}

Discrimination at the economic level induces private entrepreneurs to take risks and break the law in order to survive and develop their businesses. First of all, the high monopoly of state-owned banks on legal credit-and-loan resources and the bias of lending to state-owned enterprises, which are known also as the "national team", make the risk-control of state-owned banks on lending to private enterprises more strict than the state-owned, and it in fact forms discrimination in aspect of credit-and-loan between enterprises with different ownership (Chen et al., 2015). The discriminatory macroeconomic environment that makes it difficult for private enterprises to obtain access to credit resources, with combination of the general demand for credit resources by private enterprises, forces private entrepreneurs in China to bypass legal channels to obtain funds that are vital to the survival of their businesses.

Secondly, in the Chinese government's intervention and regulation of economic activities, private enterprises are often at a disadvantage and lose their voice in the process of economic regulation. Whenever the government regulates the relevant industries, state-owned enterprises, based on their power of speech in the national economic system and their leading position in the national economy, are able to obtain economic advantages in the regulation, while private enterprises in the position of midstream or downstream or without core compe- 
titiveness, often are stigmatized as "outdated production-capacity" in the process of government's regulation, and finally fall into the key target of being seceded or shut down.

Finally, in the current discriminatory economic environment, the protection of property rights of private entrepreneurs in China is not yet satisfactory. In some areas of China with incomplete market economy, the local government has long regarded private enterprises as the local government's "wallet", and has been apportioning exorbitant taxes to private enterprises. State employees have been also sometimes demanding bribes from private entrepreneurs. In order to maintain a good relationship with the local government, some private entrepreneurs, who understand the aforesaid "hidden rule", accept the additional task of apportionment positively in the form of "donations" (Guo, 2012).

\subsection{Phenomenon of Crimes Induced by Institutional Discriminatory Plight}

Since Chinese private enterprises face the plight of dual discriminatory institution at the political level and economic level, the crimes committed by private entrepreneurs in China are accordingly concentrated with high frequency in the "power-dependent crimes" and "economically resource-based crimes", which are produced accordingly by the above plights.

\subsubsection{Power-Dependent Crimes}

Firstly the plight induces power-dependent crimes. Under the current administration-dominant institution, the relatively weak private enterprises can only survive and develop by attaching themselves to strong government agencies and state-owned enterprises. In practice, Chinese private entrepreneurs are eager to be NPC members and CPPCC members. This interesting phenomenon reveals that, private entrepreneurs, on the one hand, are eager to attach themselves to power and make full use of power to protect their business and property rights from infringement, on the other hand, by entering the NPC and CPPCC, are able to obtain political resources and interpersonal network resources to facilitate the development and expansion of private entrepreneurs' companies. However, the private entrepreneurs who are eager to obtain political resources are as numerous as the stars, meanwhile the private entrepreneurs who can really obtain the favor and care of the power organs are only in the minority. Faced with the aforesaid plight, some private entrepreneurs have taken the illegal path of bribing personnel of government or state-owned enterprises to obtain scarce political resources. Although some private entrepreneurs may have gained temporary benefits by paying bribes or other illegal means to establish political connections, they are also in some sense victims of the discriminatory institutional plight at the political and economic levels, and are forced to commit crimes.

Power-dependent crimes also include the crimes committed by private entrepreneurs who, after acquiring the "protective umbrella of power", violate legal interests with destructive production. The negative impact of these sub-crimes 
on China's market economy is not insignificant: empirical studies have shown that private enterprises that focus more on building political connections between enterprises or entrepreneurs and the government suppress their creative production while enhancing their destructive production (He et al., 2013). The rationale is that, despite private entrepreneurs invest a lot of resources in building political connections with the government, such political connections are time-limited. The personal relationship between private entrepreneurs and government officials will gradually expire with the promotion, transfer, departure or retirement of government personnel, and it is not always possible for private entrepreneurs to establish a good personal relationship with every government personnel. Therefore, private entrepreneurs must seize the short and precious timing to make full use of the "protective umbrella of power" as quickly as possible to obtain "short and quick" economic benefits. This is a hotbed of crime for private entrepreneurs. For example, the Crime of refusing to pay remuneration for Labour, Crimes of smuggling, tax-related crimes, and Crime of polluting environment, which are rarely seen in state-run enterprises, are criminally in high-frequency with respect to private enterprises inversely (Chinese Entrepreneurial Crime Prevention Research Center, 2019).

\subsubsection{Economically Resource-Based Crimes}

The plight also breeds economic resource-based crime. As mentioned above, compared to the strong state-owned enterprises, the relatively weak private enterprises have difficulty in obtaining economic resources under the discrimination at the economic level, and even, to secure all their own economic resources is sometimes unsustainable. In order to make the enterprise survive and develop, private enterprises have to rely on illegal fundraising, tax evasion and other illegal means to take risks. For the sake of history, in the era of China's planned economy, private economy was treated with basically a negative attitude. Until the era of reform and opening up came and China clearly put forward the construction of market economy, the private economy gradually obtained its land for survival. However, due to the long historical inertia and heavy historical memory, the economic system of selective discrimination against the private economy, such as "valuing state-owned enterprises over private enterprises" and "valuing the public over the private", still exists in China today. From the perspective of a rational person, private entrepreneurs are forced to choose the path of crime in order to obtain the economic resources that they could have legally obtained in the normal institutional environment.

The above problem is fully reflected in the statistics, which indicates the concentration of crimes committed by private entrepreneurs. The data shows that the crimes of illegal acquisition of funds are the most frequent in the crimes committed by private entrepreneurs. Moreover, the typical crime of the crimes of illegal acquisition of funds, i.e. the Crime of illegally absorbing public savings, accounts for $27.21 \%$ of all crimes committed by private entrepreneurs with 693 cases in one year, which is also the crime with the highest crime rate committed 
by private entrepreneurs. In contrast, the total cases of the Crime of illegally absorbing public savings committed by state-owned entrepreneurs accounted for only $1.82 \%$ of all crimes committed by state-owned entrepreneurs in that year (Chinese Entrepreneurial Crime Prevention Research Center, 2019). The above statistics strongly prove that private entrepreneurs in China, based on the difficulty of obtaining funds in reality, have to take the abnormal path of breaking the law and committing crimes in order to raise the funds, which are necessary in the normal development and operation of their enterprises.

Economically resource-based crimes often lead to power-dependent crimes. Since private entrepreneurs generally use underground channels for financing themselves under the discriminatory institution, the investigating authorities can often easily obtain private entrepreneurs' evidence of illegal financing, which induces situation that private entrepreneurs are in the hands of the local government. This situation forces private entrepreneurs to do everything possible to maintain good relations with local government personnel in order to ensure that they are able to avoid criminal investigations and not to become another "Wu Ying". It also induces a sort of poisonous social ethos of "collusion between government personnel and businessmen" and "power-for-money deals". According to the data, the cases of Chinese private entrepreneurs committing bribery-offering crimes ${ }^{2}$ accounted for $13.08 \%$ (Chinese Entrepreneurial Crime Prevention Research Center, 2019) of all case of crimes committed by private entrepreneurs in a year. The bribery-offering crimes are the crimes with the second-highest crime rate for private entrepreneurs, except for the crimes of illegal acquisition of funds. The perfect combination of economically resourcebased crimes and power-dependent crimes has become the Achilles' heel of the development and growth of China's private economy and the endogenous tumor of China's construction of a market economy.

In a word, the above-mentioned crimes in the private economy are precisely the inevitable products of dual discriminatory plight. It calls for responses and reactions from criminal law to equally protect Chinese state-owned and private enterprises by saving Chinese private enterprises and entrepreneur from the plight.

\section{Perspective in Approach of China's Criminal Substantive Law: Is Differentiated Punishment Discrimination?}

As response in criminal substantive law for achievement in equal treatment of Chinese State-owned and Private Enterprises, Chinese scholars of criminal law have long criticized discriminatory and differential protection of the private economy in China's criminal substantive law, of which different penalties are stipulated for crimes against the state-owned economy and crimes against the ${ }^{1} \mathrm{Wu}$ Ying is a famous Chinese female private entrepreneur in Zhejiang province, who is now in prison and once was decided to impose a death penalty in the first instance verdict but reversed to impose life sentence in the final instance verdict for the sake of illegally financing her enterprise. ${ }^{2}$ Crimes of bribery-offering crimes include the Crime of offering bribes, the Crime of offering bribes by units, and the Crime of offering bribes to influential people. 
private economy. Those criticisms base on "the equal view based on the same penalty".

\section{1. "The Equal View Based on the Same Penalty" and Its Problems}

This equal view based on the same penalty manifests itself in two main aspects: The first is the unequal scope of protection. I.e., for the same type of behavior, only Infringements on the state-owned economy should be punished, while the Infringement on the private economy should not (Zhou, 2019). The most typical situation is that the crimes, as stipulated in Articles 165 to 169 of the China's Criminal Law, including the Crime of illegally operating similar business, the Crime of making illegal profits for relatives and friends, the Crime of being cheated for negligence in signing or performing contracts, the Crime of dereliction of duty of personnel of state-owned companies, enterprises and state institutions, the Crime of misuse of authority by personnel of state-owned companies, enterprises and state institutions, and the Crime of practicing favoritism and converting state-owned assets into low-value stocks, sale of state-owned property, are all aimed at protecting property and interests of the state-owned companies, enterprises, and institutions, while for infringements of the interests of the same aspect in private economy, China's Criminal Law does not stipulate any corresponding crime. The second is the unequal level in protection, that is, for the same type of behavior, the punishments for infringement of the stateowned economy are severer than those for infringement of the private economy. For example, the maximum penalty for Crime of corruption against state-owned economy is death penalty, but the maximum penalty for Crime of misappropriation in duty against private economy is only fifteen-year imprisonment; the maximum penalty for Crime of embezzling public funds against state-owned economy is life imprisonment, while the maximum penalty for Crime of embezzling funds against private economy is ten-year imprisonment (Lu, 2020).

Accordingly, critics have suggested that the legislation should be amended so that violations against both the state-owned and private economies are subject to the same penalties. On the one hand, violations against both the state-owned and private economies should be ruled by China's Criminal Law, i.e., the subjects of crimes in Articles 165 to 169 of China's Criminal Law should be expanded into inclusion of non-state entities (Li, 2006b). On the other hand, the definition of state employees in Article 93 of China's Criminal Law should be compressed and limited to state employees. The personnel of state-owned companies, enterprises, state institutions, people's organizations and non-state-owned entities should be regarded as non-state employees. Additionally, no distinction between state-owned and non-state-owned entities with respect to Crime of misappropriation in duty, Crime of bribery by personnel in company and enterprise, and Crime of embezzling funds should be made, so as to unify the protections of state-owned and private economies (Li, 2006a). 
Although Amendment (XI) to China's Criminal Law responds to the above criticism to some extent by raising the statutory penalties for the Crime of misappropriation in duty and Crime of bribery by non-state employees to life imprisonment and the Crime of embezzling funds to fifteen-year imprisonment. However, these still fall short of the maximum penalty for Crime of corruption and Crime of bribery, which is death penalty, and the maximum penalty for Crime of embezzling public funds, which is life imprisonment. Additionally, the subject of crimes in Articles 165 to 169 of China's Criminal Law are still limited to state-owned entities. It is foreseeable that the criticism of unequal protection of the private economy in the criminal substantive law will still continue.

If one thinks that the unequal treatment of criminal substantive law is only for the private economy, this differentiated protection will only occur in the field between the private and state-owned economies, however, it is not the case. On the one hand, within the crimes protecting the state-owned economy, there are also differentiated penalties. For example, if a state employee infringes state assets, the maximum sentence for the Crime of privately distributing state assets is only seven-year imprisonment, which is much lower than the maximum sentence in the case of the Crime of corruption. In aspect of the same infringement of the integrity of state employees in state-owned companies and enterprises, the maximum sentence for the Crime of offering bribe by the unit is five-year imprisonment, which is much lower than that as life sentence for the Crime of offering bribes. On the other hand, in field of property crimes without distinction of ownership, such as the crimes in Chapter 5 of China's Criminal Law, there are also crimes sentencing differentiated penalties with the same amount of crime. For example, the maximum penalty for Crime of theft is death sentence, but the maximum penalty for Crime of intentionally destroying property, a crime with infringement of property similarly, is only seven-year imprisonment, meanwhile the maximum penalty for Crime of misappropriation is only five-year imprisonment. It reveals that the difference in penalties for property crimes in China's Criminal Law is not specific to ownership, moreover, there may be another "deeper meaning".

In addition, from the empirical data, the judicial precedents in those major crimes of private enterprises do not present the "desire" for enhancing the statutory penalty. Assuming that the statutory penalties for Crime of misappropriation in duty, Crime of bribery by non-state employees, and Crime of misappropriation of funds were abnormally light and urgently needed to be raised to achieve fairness of sentencing with the logic of the "the equal view based on the same penalty", then in practice, Chinese courts would inevitably impose a large number of maximum penalties within the framework of the existing statutory penalties. However, the situation is just the opposite. In practice, Chinese courts are less likely to apply the maximum statutory penalty in the case of the above crimes. According to the data from PKULAW database ${ }^{3}$, there were 8964 judg- 
ments from Chinese courts involving "Crime of bribery by non-state employee" from January 1, 2000 to November 28, 2020, but there was only one case in which the maximum penalty with fifteen-year imprisonment was sentenced, and only one case in which the maximum penalty with fourteen-year imprisonment was sentenced. In addition, as shown in the following chart (Figure 1), it existed only a few cases in which penalties of more than ten-year imprisonment were sentenced.

It can be seen that the demand for enhancing penalties for crimes in private economic is not strong in practice. Moreover, the idea of raising their statutory penalties as same as those of state-owned economic crimes may not be in line with the purpose of penalties, let alone achieving "Everyone is equal before the law in committing crime".

\subsection{Arguments for Equal View Based on Differentiated Penalties}

In contrast to "the equal view based on the same penalty", "equal view based on differentiated penalties", which means that legislators should stipulate differentiated penalties to different defendants in accordance with distinctive identities, is factually and theoretically correct. The "the equal view based on the same penalty" advocates that criminal substantive law should treat state-owned enterprises and private enterprises equally, but they have overlooked a problem, that is, when state-owned and private enterprises are not the same under the perspective of criminal substantive law, the treatments of criminal substantive law

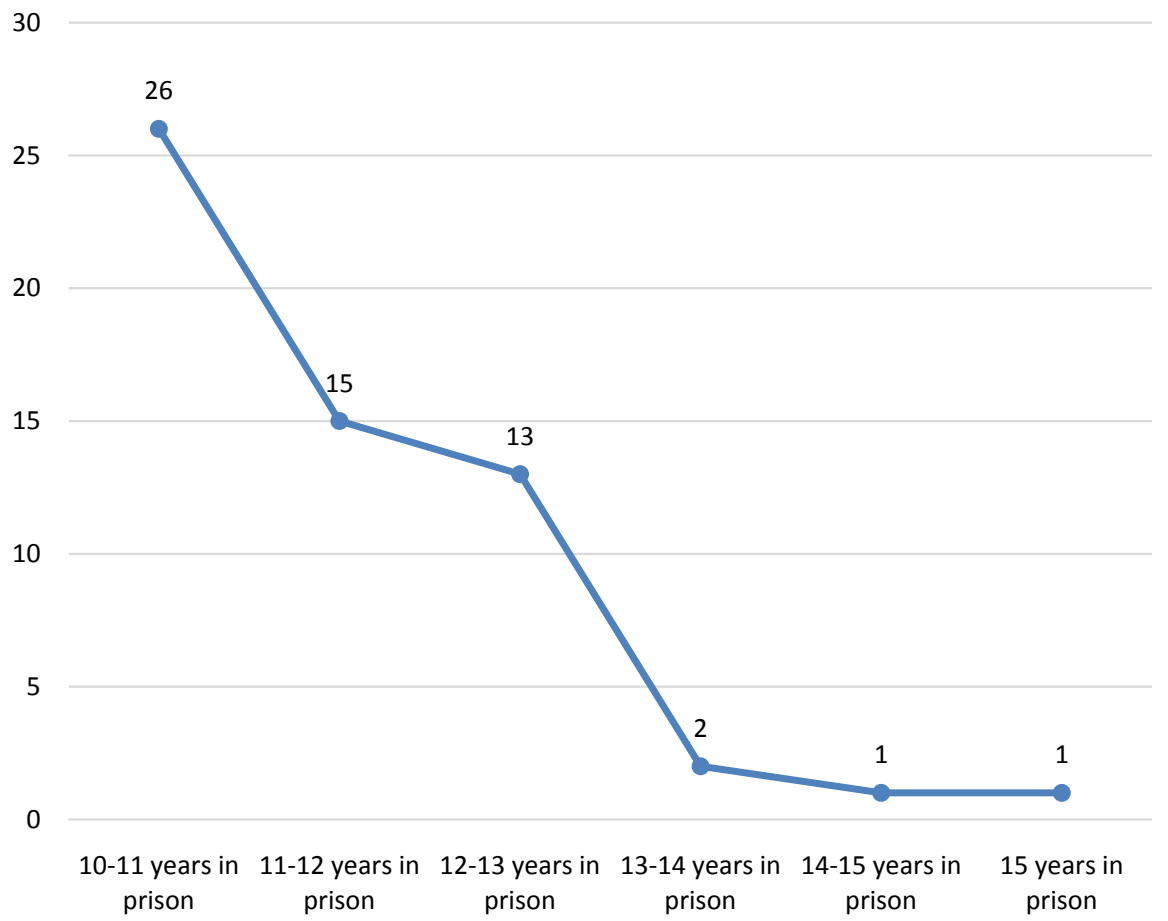

Figure 1. The Numbers of non-state employee bribery with more than 10 years imprisonment. ${ }^{*}$ All data in this chart are originated from legal-professional search engine PKULAW, http://www.pkulaw.cn/Case. 
may vary. "Everyone is equal before the law" cannot demand absolute equality, that is, non-discriminatory equality without distinguishing the characteristics of the object. A German constitutional theory of equality also holds that legislation is supposed to achieve differences in classification by covering some people and excluding others from its application through Constitutive Elements (Osterloh \& Nußberger, 2020). "The law always responds differently according to the differences between persons (Maunz et al., 2020)." When the criminal substantive law excludes pregnant women and minors from the death penalty, no one considers unequal. As Aristotle said, "Justice is considered, and also indeed is, equality, not for all, but for those who are with equality to each other (Aristotle, 1994)." The so-called "equality to each other" here is considered equal according to certain criteria. "Equality always means giving the same treatment to people who appear to be the same by a certain standard (Zhang, 1996)." It is thus argued that equality is the same (equal) treatment of people who are same (equal) in relevant respects and the distinctive (unequal) treatment of people who are distinctive (unequal) in relevant respects. This unequal treatment is of proportion to the distinctiveness (inequality) between them (Petchum, 1990). A German precedent also holds that the principle of "Everyone is equal" does not require the legislature to reject all distinctions of treatments, but it must offer "equal treatment for those substantially equal" and "unequal treatment for those substantially unequal according to the existing inequality (Decisions of the Federal Constitutional Court 1, 14)".

The question is, what is the "same person considered by the law"? i.e., what criteria should the law consider some objects as the same and others as different? Where there is a difference in treatment, there must firstly be classification that forms the difference. If the differentiated treatment is reasonable, then the classification must be reasonable; if the classification is unreasonable, then the differentiated treatment must be unreasonable. "Validity of the principle of 'Everyone is equal before the law' and a prerequisite for the validity is its compatibility with the legal order as a whole, i.e., the recognition that the law has created a legal order of differentiated treatment. As a tool for realization of differentiated treatment, the principle of equality does not challenge it, but it requires that every binding differentiated treatment in this context ought to be accompanied by objective justification or other reasonable ground (Decisions of the Federal Constitutional Court 103, 310; Decisions of the Federal Constitutional Court 108, 52)." In other words, equality implies justifiable differentiation of treatment.

In order to determine the ground of the differentiation in treatment, it must be connected with the legal purpose of the differentiation. Legislative classification is always intended to offer different legal effects to different categories of acts or objects. Each classification is linked to a certain purpose of law. A reasonable classification implies, first of all, that the legal purpose defining the classification is reasonable. Equality in law is not subjective de facto equality, but de 
jure equality. "This equality is not in aspect of "being", but "ought-to-be". Equality is always linked to the pursuit of norms on the ought-to-be level (Maunz et al., 2020), i.e., established to achieve a specific purpose of law. "If the legislator wants to establish the equality that is supposed to be there, then this equality for people with different identities, life situations and free will is measured according to the purpose of law (Maunz et al., 2020)". Examining the reasonableness of a particular distinction needs examination of the reasonableness of the purpose of the law, which achieves this kind of distinction. American constitutional theory holds that any legal classification must derive from a legally justifiable purposes, which often indicate those traditional policy goals such as protecting public safety, public health, public morals, and so on (Chemerinsky, 2019).

The ground for the differentiation of criminal substantive law must be linked to the purpose of penalties. "Everyone is equal before Criminal Law" means equality in the imposition on penalties, i.e., the reasonableness of classification in criminal substantive law is always linked to the purpose of penalties. Differences in legal classification are always associated with different legal effects, and the legal effects of classification in criminal substantive law indicate varied standards of punishment. Therefore, the review of equality in criminal substantive law is to examine whether a certain classification and its differences in penalties are consistent with the purpose of penalties. German constitutional theory also holds that equality in criminal substantive law is judged on the basis of whether the classification and its differences are compatible with the principle of the compatibility of crime and punishment (Decisions of the Federal Constitutional Court 45,187$)$. When the law regulates the punishability of the offender, this regulatory care is dedicated to the goal of the compatibility of crime and punishment (Decisions of the Federal Constitutional Court 90, 96). The criminal substantive law classifies the behaviors of differentiated subjects according to their status and thus allocates differentiated penalties. To judge whether this differentiation in penalties is in accordance with the principle of equality means judging whether the penalty is in accordance with the compatibility of crime and punishment. However, different theories of the purpose of penalties contain different requirements for the compatibility of crime and punishment, and thus the review in principle of "Everyone is equal before Criminal Law" is ultimately a test of whether the classified punishments conform to the correct theory of the purpose of penalties.

The theory of the purpose of penalties has traditionally been divided into two parties: theory of retribution and theory of prevention, but today few scholars support only one theory between retribution or prevention. Most support theory of unificationism, which holds that the task and purpose of penalties are not considered in isolation from guilt-satisfaction, individual prevention, or general prevention, but in combination with retribution and prevention (Radtke, 2020). "However, since the penal purposes of retribution, deterrence and correction are 
contradictory in nature, it is necessary to reconcile these contradictory phenomena and reduce the contradiction between the different penal purposes to a minimum, so that they can co-exist and mutually effective (Lin, 1998)." The mainstream German theory holds that the purpose of punishment is ultimately to prevent crime, which is deemed as origin, but should also be limited by the principle of culpability in the sense of retribution theory (Kindhäuser \& Zimmermann, 2020). Accordingly, when the penalty is raised based on the need for crime-prevention, it should be subject to the limitation of theory of retribution, i.e., the penalty should not exceed the requirement of retribution for the sake of prevention. However, when the penalty is decreased based on the need for prevention, can it fall below the lower limit of the retribution requirement? The answer is absolutely yes. According to the American scholar Professor Hart, "the grounds for deciding that which acts should be punished as crimes are general prevention and individual prevention, besides the main basis for deciding that under what conditions the punishment should be imposed and the intensity of the assigned punishment is retribution, but meanwhile general prevention and individual prevention can also be the basis for exemption from imposition of the punishment and reducing the intensity of the assigned punishment (Hart, 1968)." According to Hart's "unificationism of punishment", Chinese domestic scholars have proposed the idea of "retribution determines the upper limit of punishment and utilitarianism mitigates the lower limit". The former refers to that when the punishment required by the need for crime-prevention is heavier than the punishment required by the severity of the crime, the maximum punishment shall not exceed the punishment required by the severity of the crime, i.e., the need for prevention shall not override the severity of the crime. The latter refers to that when the punishment required by the need for crime-prevention is lighter than the punishment required by the severity of the crime, the punishment lighter than that required by the severity of the crime can be imposed, i.e., instead of imposition of the corresponding heavy penalty according to the severe crime, a relatively lighter penalty can be imposed on the ground of the need for prevention (Qiu, 1999). In short, according to the theory of unificationism of punishment, retribution determines the upper limit of the imposition of punishment, but with this precondition, Utilitarianism can exempt or reduce the punishment.

According to the view of equality from theory of unificationism of punishment, it is possible for two crimes that are identical in retributive requirements (both are identical with respect to illegality and responsibility) to maintain differentiation in aspect of penalties due to differences in the preventive requirements of the two crimes. For example, the lesser preventive requirement of one crime results in a lighter penalty, but this difference is consistent with the principle of equality. This phenomenon is pretty common in legislation. For example, the maximum penalty for the Crime of theft is life imprisonment, but the maximum penalty for Crime of misappropriation, which is also a profit-gained 
property crime, is only five-year imprisonment. The reason is that the preventive pressure for the Crime of misappropriation is much lower than that the Crime of theft. Theft is one of the crimes with the highest incidence rate, and the pressure of general prevention is undoubtedly high. Meanwhile the Crime of misappropriation presupposes that the perpetrator has already taken possession of the property originally owned by another person, which means that if a person cannot take possession of another person's property in advance for some legal reason, he cannot commit the Crime of misappropriation. The Crime of misappropriation requires a factual "God-given" premise for the commitment of the crime, while the Crime of theft does not require this premise. Due to this factual premise, the prevention-pressure of the Crime of misappropriation is much lower than that of Crime of theft, because not every wrongdoer has the opportunity to commit this crime. Therefore, even though one commits Crime of theft and Crime of misappropriation with the same amount and thus the retribution requirements for both crimes are the same, the latter crime has a much lighter preventive pressure than the former. Based on the "utilitarianism mitigates the lower limit", the penalty for the latter is much lighter than the former. Similarly, for the same reason, the statutory penalty for the Crime of intentionally destroying property is lighter than the Crime of theft. Because Crime of theft is a profit-gained crime and Crime of intentionally destroying property is a nonprofit-gained crime, more people are willing to commit the former than the latter, and the latter has less preventive pressure, thus its penalty is lighter.

Similarly, the differentiation in criminal punishment between crimes against the private economy and the state-owned economy is in line with the equal view of theory of unificationism of punishment, because the preventive pressure on the former is much lighter than that on the latter. When the amounts of crimes are equal, it may be considered that the retributive requirements of punishment for crimes against the private economy and the state-owned economy are equal, but the pressure of prevention is not the same for the two. The protection of legal interests can be divided into the protection of criminal law and the protection before criminal law. Criminal law is always complementary to the protection of legal interests. Only when the protection before criminal law is inadequate, criminal law can intervene. In other words, if the protection before the criminal law is sufficient, the criminal law can intervene at a lesser level, which is manifested in the lower pressure of prevention of criminal substantive law. For example, China's Criminal Law does not stipulate for the Crime of incest, not because incest is absolutely harmless, but because moral taboos can be strong deterrence to such behavior generally, therefore there is naturally no need for intervention from criminal law. Because of the institutional problem with respect to separation of management and ownership, state-owned assets are often at a disadvantage compared to private enterprises' asset in terms of self-protection of the integrity of their property and staffs, which is often discussed as the risk of loss of state-owned assets. Compared with private enterprises, the management 
of state-owned assets has serious institutional shortcomings, including: the long-term absence of the owner of state-owned assets, unclear property rights, failure to make clear the relationship between the ownership, power of management and power of operation in state-owned assets, and then there are various defects in aspect of personnel system, incentive system, and supervising system (Wang, 2019). On the contrary, private enterprises, due to the close relationship between owners and operators (both are even the same), are instead able to establish a tighter protection system for corporate assets. Moreover, some of the ways in which state-owned assets are lost, such as those caused by false declaration of debts, false appraisal of assets, and defrauding state support in the process of restructuring of enterprises, assets lost in Sino-foreign joint ventures and cooperation, and state-owned assets lost in the bankruptcy of enterprises (Fu, 2011; Liu, 2017), are less common in private enterprises. According to relevant information, the loss of state-owned assets is 80-100 billion yuan per year (Fu, 2011), which is incomparable to the loss of private assets. Lack of asset protection of state-owned enterprises requires a higher level of protection by criminal substantive law, which is manifested in the greater pressure of general prevention of those crimes. Since the general preventive pressure of crimes against the private economy is lighter than that of the state-owned economy, fewer and lighter penalties can be imposed. For this reason, in practice, Chinese judges are not willing to impose heavy sentences on the offenders committed the Crime of bribery by non-state employee in private enterprises, and thus, as mentioned above, only one case of fifteen-year imprisonment was found in the PKULAW database. Therefore, stipulation of lighter penalties for the crimes against private enterprises is a requirement of the "utilitarianism mitigates the lower limit" and is in line with the view in equality of theory of unificationism of punishment.

\subsection{Staged Conclusions}

After we located the dual discriminatory institutional plight faced by Chinese private enterprise and pointed out the inevitability of the plight-induced crimes committed by Chinese private enterprise, for reaching out to the solution, we are examining the approach of criminal substantive law by testifying the ground of the general viewpoint of Chinese scholars, i.e. the equal view based on the same penalty. However, we found that the equal view based on the same penalty is not in line with the correct theory of purpose of penalties, on the opposite, the equal view based on the differentiated penalties, which imposes on different people in accordance with distinctive identities, is consistent with correct theory of purpose of penalties, which means unequal treatments in criminal substantive law is of justification and should be maintained.

In a word, approach in criminal substantive law is unable to and not ought to work in equal treatment of Chinese state-owned and private enterprises. We must find another alternative justified and workable solution for achievement of equal treatment of Chinese state-owned and private enterprises. 


\section{Switch to Approach of Procedural Law: The Correct Way to Achieve Equal Treatment}

Since the approach of substantive law are unable to and not ought to work in equal treatment of Chinese private enterprises and Chinese private enterprises indeed face the forementioned institutional plights of dual discrimination, approach of criminal procedural law should be explored if it is a correct alternative solution for achievement of equal treatment. In the field of criminal procedure law, due to the fact that most of the crimes in the field of private economy are committed by private entrepreneurs induced by the dual discriminatory institution, the position of substantive equality under the rectificatory justice should be advocated. From the standpoint of substantive equality, the procedural law of equal treatment for the private economy can better protect the legitimate rights and interests of Chinese private enterprises and entrepreneurs as the relatively disadvantaged group, and can also better realize the basic value of fairness and justice in law, moreover, can better promote the healthy development of China's market economy.

\subsection{The Raise for Issue of Equality of Treatment in China's Criminal Procedural Law}

In recent years China's judicial authorities are gradually correcting the discriminatory treatment imposed on private economic subjects compared to the past in China's Criminal Procedural Law, and act with more emphasis on a protection-oriented posture toward private economic subjects. The reform in the practice has also gained a lot of support in theory (Lu, 2020; Yin \& Liu, 2018; Zhao \& Zuo, 2017).

With regard to how to truly achieve equal treatment between the state-own economy and the private economy in criminal procedural law, scholars in China have different views based on different standpoints. On the one hand, some scholars believe that the judicial procedure of criminal cases involving the private economy should strictly follow the three principles of in dubio pro reo, of nullum crimen sine lege, and of application of the old law with the exception of a less punishment in the new law (Yuan, 2018). Some scholars also believe that the key to achieving equal treatment in the procedural law lies in reformation of the criminal case-filing system, in which the discretionary power of Public Security Bureau for case-filing is not subject to supervision (Zhang, 2020). Some scholars also believe that private enterprises should be protected systematically and comprehensively in four aspects: jurisdiction of case-filing, physical coercive measures, coercive measures on property, and property-confiscation procedures (Xiong, 2019). Some scholars even argue that physical coercive measures should be strictly applied in the criminal cases related to private economy from a balanced perspective, but oppose the conditional non-prosecution or other forms of judicial preferences granted to private enterprise (Li, 2020a). On the other hand, some practitioners are calling for the procuratorial authorities' enhance- 
ment of the supervisory function of case-filing, of the approval function of arrests, and of the discretionary function of public prosecutions in aspect of criminal cases involving the private economy (Lou, 2020). Some practitioners also advocate the implementation of special protective policies for private enterprises and seek to achieve precise protection for private enterprises in legislation and justice (Zhao, 2020b). In general, both academic and practical circles share the common goal of pursuing the realization of equal treatment between the state-owned economy and the private economy in procedural law, but meanwhile differences and divergences present with respect to the basic concept and the specific ways to this goal.

However, the above suggestions do not address the fundamental question, i.e. whether the equal treatment of private enterprises in procedural law violates the principle of equality of all persons in procedural law. In other words, what is the justification for granting private enterprises more judicial preferences in procedural law compared to state-owned enterprises? For example, some scholars are in favor of strict application of coercive measures in criminal cases related to the private economy, but also oppose the conditional non-prosecution or other forms of judicial preferences for private enterprises. The idea is actually incompatible in itself, because of the logical contradictions with failure to answer the aforesaid fundamental question. To answer this question, we must first explain the substantive meaning of "equality" in principle of equality of all persons in procedural law. The author believes that the theory of rectificatory justice, which emphasizes both distributive justice and the principle of differentiation, can provide a good philosophical basis for the substantive connotation of equality.

\subsection{Jurisprudential Basis of Equal Treatment in China's Procedural Law}

\subsubsection{Rectificatory Justice as a Philosophical Foundation}

The idea that proportional equality does not prohibit reasonable differences is written in Aristotle's discussion of issues concerning justice. Aristotle pointed out that "there are two main categories of specific justice and its corresponding actions, one is justice expressed in the distribution of honor, money, or other divisible common wealth. The other type is justice that acts as a corrective in private transactions (Aristotle, 2012)." It can be seen that Aristotle divided justice into two parts that are independent of each other in meaning. The former is called "distributive justice" and the latter is named "rectificatory justice", in which Aristotle's argumentative logic on rectificatory justice has been filled with substance in contemporary times at Rawls.

Rawls' theory of justice focuses on the distribution of public wealth. According to Rawls' theory, the prerequisite for people to sustain their lives in society is the equal distribution of resources for the "primary goods". Rawls achieves justice through the equal distribution of the primary goods, and in doing so must follow two hierarchical principles of justice proposed by Rawls. The first is the Rawls' first principle of justice, that is, "Each person is to have an equal right to 
the most extensive total system of equal basic liberties compatible with a similar system of liberty for all (Rawls, 1971)." On the basis of satisfying the first principle, Rawls proposed the second principle of justice in response to the de facto inequality in real life caused by people's innate advantages in society, among which the first clause of the second principle is worth noting. "Social and economic inequalities are to be arranged so that they are both: to the greatest benefit of the least advantaged, consistent with the just savings principle (Rawls, 1971)." i.e. the difference principle. According to Rawls, in order to achieve distributive equality, it is necessary to resort to the difference principle by compensating the least advantaged class to a certain extent, i.e., through the biased distribution of the primary goods in society, so as to achieve substantive equality. The theory of rectificatory justice provides the philosophical basis for the interpretation of the substantive meaning of "equality" in the principle of equality of all persons in procedural law.

\subsubsection{Advocacy of Substantive Equality Position under Rectificatory Justice}

From the basis of the theory of rectificatory justice, the principle of equality of all persons in procedural law should place emphasis on substantive equality with focusing on the reinforcement of disadvantaged groups in criminal prosecution. The original equality-dualism has not satisfactorily solved the problem of reinforcement. In contrast, the modified equality-dualism draws on the theory of rectificatory justice and starts from the position of substantive equality, which makes corrections to the shortcomings of traditional dualism in different aspects and provides more convincing answer to the aforesaid question.

1) Original Equality-Dualism

Regarding the equality of all persons in procedural law, the traditional view is that the principle of "equal application of the law to all citizens" requires, on the one hand, that the judicial organs must treat all citizens equally in criminal prosecution; on the other hand, all citizens must receive equal protection of legal rights and interests in criminal prosecution. The judicial organs shall not arbitrarily deprive any citizen of the procedural rights and interests of the law. This is the original equality-dualism of "equal prosecution" and "equal protection" of equality of all persons in procedural law (Chen \& Xu, 2002). The justification behind this sort of dualism is based on the theory of formal equality in law.

\section{2) Revised Theory of Dualism}

A number of scholars have recognized the drawbacks of the aforementioned theory of original dualism. With regard to equality of all persons in procedural law, the scholars have proposed a theory of equality-trialism, which is a complement to the dualism. On the basis of the dualism, the trialism proposes to guarantee the due rights of all participants in the proceedings, that is, to add "equal treatment" to "equal prosecution" and "equal protection" (Luo, 2007). Another kind of trialism emphasizes the equal status of the prosecution and defense in criminal procedure, and advocates to reinforce the disadvantaged com- 
pared to the normal (Yang, 2008). At the same time, some commentators advocate that the new dualism, of which "equal procession of rights in procedure" replaces "equal protection" and special preferential measure should be taken for protection of the rights of the relatively disadvantaged (Yu, 2010).

\section{3) Theory of Substantive Equality}

In author's opinion, the above-mentioned revised solutions for the theory of original equality-dualism are all based on the justification that substantive equality is superior to formal equality. ${ }^{4}$ It also can be called the theory of substantive equality. The theory of substantial equality is in the same way of thinking as the theory of rectificatory justice. The difference principle in the theory of rectificatory justice emphasizes the reinforcement to the disadvantaged for achieving justice. The theory of substantive equality is created for the purpose of achieving substantive fairness and justice in procedural law, and its way of thinking is also to reinforce the disadvantaged litigants. We can see the extension from the philosophical theory of rectificatory justice to the theory of substantive equality in the field of procedural law. Theory of substantive equality based on the theory of rectificatory justice is worth advocating for three reasons.

Firstly, the theory of rectificatory justice provides justification for the theory of substantive equality. In the real human world, in order to achieve fairness and justice, it is necessary to reinforce the least advantaged differently. The formal equality theory, which treats all litigants equally and rejects any form of judicial preference, is the real source of the failure to achieve equal treatment in procedural law. On the contrary, the theory of substantive equality advocates differentiated protection for disadvantaged litigants, preferential treatment to disadvantaged litigants in an appropriate range, and construction of a fair play field where the powerful and the disadvantaged can confront each other as much as possible in criminal procedure.

Secondly, the theory of substantive equality based on the theory of rectificatory justice is more in line with the social values of the general people. The theory of substantive equality is not as lacking in social value and support from general public as attacked by the formal equality theorists. On the contrary, it is actually more in line with the general social values to grant judicial preference to the disadvantaged litigants appropriately. Especially in criminal procedure the contrast between the powerful side and weak side is pretty obvious, which further highlights the application of the principle of substantive equality in procedural law to reinforce the disadvantaged litigants as a matter of course.

Thirdly, the position of substantive equality can better achieve equal treatment of procedural law for the purpose of protecting our private economy. As mentioned earlier, crimes committed by private enterprise are essentially inevitable products under the dual discriminatory institutional plight. As victims of ${ }^{4}$ Although most of the commentators refer to "the unity of formal and substantive equality", "the organic combination of formal and substantive equality", etc. The fact that the classification both of form and substance in the concept of equality implies a certain recognition of the priority of substantive equality. 
the aforementioned plight, it is more difficult for private enterprises as the disadvantage to secure their safety after they fall into the criminal procedure. But at the same time, the interests of state-owned enterprises are disproportionately overprotected for the sake of their supremacy, which can be called a legal privilege ( $\mathrm{Li} \& \mathrm{Ye}, 2012$ ). If we want to truly achieve equal treatment in procedural law, we must make efforts to enhance the judicial protection of private enterprises and improve judicial preferences to private enterprises from the standpoint of substantive equality.

\subsection{The Specific Method to Equal Treatment in China's Criminal Procedure Law}

The equal treatment of procedural law in China should focus both on the application of the position of substantive equality in the specific institution of procedural law and the grant of appropriate judicial preferences in the criminal procedure to private enterprises and private entrepreneurs. This is reflected in the two major aspects of procedural strategies in application of procedure law, i.e. improvement in the application of China's corporate compliance deferred prosecution institution and restriction of custody against personnel in Chinese private enterprises, as detailed below.

\subsubsection{Improvement in the Application of China's Corporate Compliance Deferred Prosecution Institution}

The corporate compliance deferred prosecution institution originated in the United States and is now widely accepted in the United Kingdom, Canada, France and other countries. The earliest and most influential deferred prosecution institution in the world is the U.S. deferred prosecution agreement institution. The institution consists of an agreement between the prosecuting authority and the company involved in the prosecution. The agreement provides that the company involved in the crime will construct, improve and implement a compliance plan within a certain period of time, during which the company must be monitored by compliance supervisors appointed by the prosecuting authority. After the expiration of the period, the prosecuting authority will decide whether to dismiss the charges against the company involved in the case if it passes the evaluation of the compliance plan.

With regard to Improvement in the application of China's corporate compliance deferred prosecution institution, opinions from Chinese scholars revolve around the reform of the conditional non-prosecution institution, leniency institution of admission of guilt and punishment with factor of compliance and the relationship between the two by drawing on the experience of foreign countries and international organizations. Four different thoughts have been formed. Some scholars suggest that the current conditional non-prosecution institution should be reformed with corporate compliance, which should be the core institutional basis of China's corporate compliance deferred prosecution institution (Liu, 2021). On the contrary, some scholars suggest that China's corporate com- 
pliance deferred prosecution institution shall be placed in the examination-norms of the leniency institution of admission of guilt and punishment ( $\mathrm{Li}$, 2018; Li, 2020b; Ma, 2020). Some scholars also hold a theory of compromise, that is, the mechanism of compliance is compatible both in the leniency institution of admission of guilt and punishment and the conditional non-prosecution institution (Chen, 2020a; Zhao, 2020a). Other scholars reject all the aforementioned options of compliance in criminal law and suggest that there should not be a rush to build corporate compliance deferred prosecution institution at the criminal law level. China should firstly establish institution of compliance at administrative level as a priority (Tian, 2020).

We believe that, due to the institutional environment of dual discrimination against private enterprises in China, it is imperative to improve corporate compliance deferred prosecution institution. China's private enterprises and entrepreneurs are facing a high risk of breaking the criminal law if they are not careful, the deferred prosecution institution with corporate compliance can not only give private enterprises and entrepreneurs, which have not established an internal compliance institution or just established an unsatisfactory one, a chance to reform themselves. Corporate compliance deferred prosecution institution can also compel private enterprises with weak awareness of risk to establish a satisfactory institution of compliance by mandatory means, which is fully consistent with the requirements of the position of substantive equality. As to what kind of corporate compliance deferred prosecution institution should be taken in China, the author proposes a two-step program, that is, firstly the application of leniency institution of admission of guilt and punishment for private enterprises should be the precondition; secondly the modified conditional non-prosecution institution should be the backbone. Specific reasons and institutional design are detailed below.

1) Precondition as Application of Leniency Institution of Admission of Guilt and Punishment for Private Enterprises

In the problem of relationship between leniency institution of admission of guilt and punishment and corporate compliance deferred prosecution institution with respect to China's private enterprises, the plan, in which the former is the precondition of the latter, is the optimal solution. Specifically, firstly in the examination of prosecution stage, after procuratorial authorities confirm the application of the private enterprises to participate the leniency institution of admission of guilt and punishment, the enterprises involved in the case can only apply to the procuratorial authorities for the application of the corporate compliance deferred prosecution institution. Secondly, the corporate compliance deferred prosecution institution should be applied as an incentive mechanism (Chen, 2020b) for private enterprises to participate in leniency institution of admission of guilt and punishment. The purpose of the leniency institution of admission of guilt and punishment is to focus limited judicial resources on difficult cases, in which the defendants do not plead guilty (Zhang, 2019). In order 
to achieve the purpose, the application of corporate compliance deferred prosecution institution to the defendants may facilitate defendants' active action to plead guilty. Finally, to set leniency institution of admission of guilt and punishment as precondition can prevent in the field of crimes of enterprises the leniency institution to become burden in procedure law. Applying corporate compliance deferred prosecution institution primarily will inevitably weaken the incentive of the enterprises to apply for leniency institution of admission of guilt and punishment, because applying for a leniency institution means facing continuous expenses in prosecutions, lengthy judicial procedures and uncertain results of verdicts, which is not a good deal from "cost-benefit" perspective.

\section{2) Kernel as Modified Conditional Non-prosecution Institution}

In the current situation of the high incidence of crime in the field of private enterprises, the modified conditional non-prosecution institution as the backbone of the corporate compliance deferred prosecution institution is a useful judicial exploration to protect the healthy development of the private economy and is worthy of strong advocacy. The author suggests that China should modify the current conditional non-prosecution institution from the five aspects of Subjects, Crimes, Initiation, Context and Review, so as to improve the application of China's own corporate compliance deferred prosecution institution. The details are as follows.

For the modification of applicable subject of the conditional non-prosecution institution, the legislation should, in principle, grant the permissions of applications of corporate compliance deferred prosecution institution to all enterprises with different ownership, which involve private enterprises. However, this does not mean that in practice, all enterprises can be granted application for corporate compliance deferred prosecution institution. For the private enterprises lack of financial ability to satisfy the requirements in corporate compliance deferred prosecution institution, the applications of the institution should be reduced or even dismissed. In addition, for those enterprises involved in recidivism, in re-commitment with crimes within five years after passing the review of corporate compliance deferred prosecution institution for prior crime-commitment, or using criminal activity as its main source of profit, the application of the institution should also be dismissed.

In order to realize the judicial preference for the private economy, in aspect of modification of applicable crimes for conditional non-prosecution institution, the legislation should add the crimes with high incidence-rate in the field of private economy into the extent of applicable crimes in conditional non-prosecution institution. Most of the economic crimes in Chapter 3 of the Criminal Law, as well as the crimes of offering bribery in Chapter 8 , should be added. However, there are some crimes in Chapter 3 that infringe on both the economic order and the personal interests of citizens, which should not be added.

In aspect of modification of initiation of conditional non-prosecution procedures, the procuratorial authorities also need to the select the "seed enterprises", 
which are suitable for participation in reform of criminal compliance. The selection should base on the degree of willingness of the private enterprises to participate in criminal compliance, the possibility of effective formulation and implementation of compliance plans, the degree of social and economic contribution and other comprehensive considerations. In addition, the procuratorial authorities can explore public hearing institution for corporate compliance deferred prosecution institution. It means that the procuratorial authorities hold open-topublic hearings in criminal cases with a certain degree of social influence in the private economy, when reviewing whether to grant qualification of participation of corporate compliance deferred prosecution institution to private enterprises.

Regarding the content of the compliance inspection, the author believes that the main parts of investigation should be oriented towards the subjective willingness of the private enterprises to cooperate with the procuratorial authorities for criminal compliance and the objective effectiveness of the private enterprises' compliance plans. The former should include whether there are omitted crimes or new crimes committed by private enterprises during the period of inspection, whether the private enterprises directly or indirectly do not cooperate with the supervision of the procuratorial authorities or other supervisory bodies, or whether there are significant false records or omissions in the materials submitted by the enterprise for compliance inspection, etc. Regarding the latter, there is currently no unified program for assessing the effectiveness of compliance plan in China. In the author's view, the relevant programs of the foreign countries or the regulatory documents of international organizations can be used as reference for China's improvement of the application of corporate compliance deferred prosecution institution. According to the June 2020 edition of the Evaluation of Corporate Compliance Program issued by the U.S. Department of Justice, the effectiveness of the compliance program can be judged from three basic issues. The first is whether the compliance program is well-designed; the second is whether the compliance program is being applied with earnestness and in good faith; and the third is whether the company's compliance program is of effectiveness in reality. Under each of these elements, there are more specific assessing criteria. Also, the Summary of World Bank Group Integrity Compliance Guidelines published by the World Bank suggests to examine the effectiveness of compliance programs from additional dimensions. ${ }^{5}$

With respect to the review of results of compliance, staged reviews can be conducted in accordance with the different stages of the process of compliance. Staged inspection reports as a form in corporate compliance should be issued by the prosecuting authority in conjunction with the compliance supervisors and those reports shall be available to the public through internet and other channels. At the end of period of inspection, the procuratorial authorities and the compliance supervisor shall conduct a comprehensive and final inspection. The ${ }^{5}$ There are eleven dimensions: Prohibition of Misconduct; Responsibility; Risk Assessment; Internal Policies; Policies for Business Partners; Internal Controls; Training and Communication; Incentives; Reporting; Remediation of Misconduct; and Collective Action. 
results of inspection shall form a written report and serve as a direct basis for the procuratorial authorities to decide whether to formally withdraw the prosecution to the private enterprise.

\subsubsection{Restriction of Custody against Personnel in Chinese Private Enterprises}

The application of physical coercive measures including custody is the most important aspect of the criminal procedure for private entrepreneurs. Even though Chinese criminal policy in recent years favors protection of private enterprises, it must be seen that the main reason is the relatively lenient criminal policy in China for private enterprises in recent years, rather than that the Chinese judicial authorities have taken the initiative to implement the position of substantive equality in procedural law to judicial activities. Restriction of custody against personnel in Chinese private enterprises cannot rely only on short-term criminal policy, but the need to take advantage of the current good timing, in which the Party and State are making effort to advocate equal protection of the private economy, and to promote the restriction of custody against personnel in Chinese private enterprises in criminal procedure. We believe that the following contents of four aspects should be implemented for promotion for criminal cases involving Chinese private economy.

1) Strictly Supervising the Application of Examination-Provisions for Danger to the Society in Examination of Arrest

On the one hand, it is necessary to break the judicial inertia that the examination of danger to the society in criminal cases involving private economy is just a mere formality. Examination of danger to the society, from the angle of public security bureaus, is to fill out the "form of evidence of danger to the society" (hereinafter referred to as "form of evidence"), when public security bureaus transfer the case to procuratorates for conduction of examination arrest. From the perspective of the current judicial practice, the investigative authorities will use at least one kind of specific clauses of all preset situations of danger to the society from the Evidence Form in order to improve the success-rate of permission of arrests. For criminal cases involving private economy, the supervision of examination of the danger to the society conducted by the investigators should be improved, and the investigators should be punished for the incorrect identification when the private entrepreneurs as criminal suspects who really did not breach any clause contained in the "Form of evidence". On the other hand, the current standard of examination of danger to the society should be reasonably clear with specific contents, corresponding parameters and percentage of parameters in the examination, in order to fully and truly reflect the danger of suspects in criminal cases in aspect of private economic. The essence of criminal cases involving private economy are less dangerous than the same type of criminal cases involving the state-own economy to the society, therefore private enterprises and private entrepreneur should receive judicial preferences in procedural law in the examination of danger to the society, which is also the specific 
embodiment from the position of substantive equality.

2) Establishing Open-to-public Institution of Examination of Arrest and Examination of the Necessity of Custody

First of all, institution of written reasoning should be established for the procuratorial authorities to respond to the opinions of attorneys in the procedure of examination of arrest and examination of the necessity of custody. The institution of written reasoning can better protect the right of defendants in criminal cases involving private economy. Through the prosecutor's response with written reasoning, the defendants' side can be clearly informed of the reasons for the prosecutor's decision, so that the attorneys can focally seek new evidences or provide new legal opinions based on the reasons listed by the prosecutors. At the same time, prosecutors are forced to take a more cautious approach in examination of arrest and examination of the necessity of custody because of the need to produce formal written legal documents. Secondly, the institution of open-topublic examination of the necessity of custody in criminal cases involving private economy should be promoted. A number of scholars have proposed to reform from the current inward examination, which is not open to public, to open-to-public examination in the form of hearings ( $\mathrm{Gu} \& \mathrm{Li}, 2013$; Xie, 2016; Zhang, 2015). The author agrees with the above-mentioned scholars and believes that for criminal cases involving private economy with certain social impact, the hearing can be held by the prosecutor in charge of the case. In this way, the prosecutor invites leaders in his or her procuratorate, police officers in charge of the case, defendants' attorneys in the case, representatives of the NPC or the CPPCC without involvement in the case, and professors from universities to attend the hearing of examination of arrest or examination of the necessity of custody together and express their opinions. Finally, the highest procuratorial authority also stipulates in the relevant judicial interpretation (Supreme People's Procuratorate, 2016), that except for three cases of "state secrets, commercial secrets, personal privacy", procuratorate can undertake open-to-public examination of the necessity of custody. The judicial interpretation affirms that open-topublic examination of the necessity of custody can be applied to most criminal cases in aspect of private economic.

3) Granting Chinese Private Enterprises More Chances to Application of the Examination of the Necessity of Custody

Criminal cases involving the private economy should be granted more chances to application of the examination of the necessity of custody, for three reasons. The first is feasibility. The relevant laws and judicial interpretations do not limit the applicable scope of examination of the necessity of custody, in other words, applying examination of the necessity of custody to the criminal cases involving private economic is completely legitimate and reasonable. The chief procurator of China's highest procuratore also proposed that “...Fully consider the characteristics of the private economy...supposed there is opportunity to take more alleviated and lenient measures in accordance with the law, not to use cus- 
tody, seizure of property or other mandatory measures (Supreme People's Procuratorate, 2021)." The second lies in the necessity. The private economy plays an important role in the process of building a market economy in China, and the imposition of criminal detention on the private entrepreneurs causes such adverse consequences as collapse of enterprises, devaluation of asset, job-loss of employee, etc. Therefore, criminal cases involving the private economy should increase the frequency of application of the examination of the necessity of custody. When the private entrepreneurs in custody are proved without ongoing necessity of custody, they should be promptly released, so that they can return to society and continue to operate their businesses. The third is reasonableness. As mentioned above, for the sake of China's dual discriminatory institution, the private entrepreneurs are disadvantaged. Based on the position of substantive equality, the private enterprises and private entrepreneurs should enjoy the corresponding judicial preferences in procedural law. Without any doubt, application of the examination of the necessity of custody is one of the aforementioned specific judicial preferences.

4) Stimulating Prosecutors' Motivation to Conduct Examination of the Necessity of Custody

On the one hand, the law should be amended so that examination of the necessity of custody should be a mandatory and binding part for the investigative authorities in criminal procedure and the function of legal supervision of the procuratorate can be realized in reality. At present, the examination of the necessity of custody belongs to recommendatory examination-system, which means Letters of Recommendation issued by procuratorates are binding but not mandatory, while the examination of arrest belongs to decisive examination-system, which means Decisions of Arrest issued by procuratorates are both binding and mandatory. There is a clear distinction between the two. However, the final results of both examinations are whether to restrict the personal freedom of the defendants by means of custody. In addition, the forms and elements of both examinations are quite similar. From the perspective of internal consistency of legal system, the examination of the necessity of custody and examination of arrest can and should be placed under the same examination-system. As for the question, in which examination-system both examinations should be placed, since both are directly related to the most important right i.e. personal freedom of defendants, the answer is here: it is more appropriate to apply decisive examination-system. On the other hand, the performance evaluation of the procuratorial system should be more lenient to responsible prosecutors in criminal cases involving the private economy, which specifically reflects in exemptions from the responsibility of responsible prosecutors for their mistakes in criminal cases involving the private economy. Only if responsible prosecutors are exempted, they are able to unlock the ideological constraints. Of course, if the responsible prosecutors deliberately made mistakes in procedure of examination of the necessity of custody, they should naturally be subject to appropriate sanctions. When the circumstances are serious, they shall be investigated and 
prosecuted for criminal responsibility.

\subsection{Summary}

As the approach of substantive law is unable to and does not ought to work in equal treatment of Chinese state-owned and private enterprises, we begin to examine the approach of procedural law for the solution of equal treatment. On the basis of the theory of rectificatory justice as a philosophical foundation, the theory of substantive can be the standpoint and guideline in criminal procedural law for testifying and identifying the correct specific methods for realization of equal treatment. Here, we put forward two specific methods, of which the first is improvement in the application of China's corporate compliance deferred prosecution institution and the second is focusing on the restriction of custody against personnel in Chinese private enterprises. We demonstrate that these methods based on the theory of substantive equality in criminal procedural law can be effective in achieving equal treatment of Chinese state-owned and private enterprises. That justifies our presumption: Switch to approach of procedural law is the correct way to achieve equal treatment.

\section{Final Conclusion}

The rejection of the equal view based on the same penalty and the justification of the equal view based on differentiated penalties means that the approach of criminal substantive law supported by many Chinese scholars cannot and should not respond to the institutional plight of dual discrimination, in which Chinese private enterprises and entrepreneurs struggle to survive. The approach of criminal procedural law, which is based on substantive equality position under rectificatory justice, can be an alternative justified and workable solution for achieving equal treatment of Chinese private economic, that is the reason why the switch from the approach of criminal substantive law to a new approach of criminal procedural law is inevitable. The approach of criminal procedural law still needs explanation and clarification of specific workable methods, which are divided into 2 parts in procedural strategies in application of procedure law: improvement of application of corporate compliance deferred prosecution institution and restriction of custody against personnel in Chinese private enterprises. We believe this switch will enable Chinese private enterprises to achieve equal treatment in criminal law.

\section{Conflicts of Interest}

The authors declare no conflicts of interest regarding the publication of this paper.

\section{References}

Aristotle (2012). Aristotle: Nicomachean Ethics. University of Chicago Press.

Aristotle (1994). The Complete Works of Aristotle (Vol. 9). China Renmin University Press. 
Chemerinsky, E. (2019). Constitutional Law (6th ed.). Aspen Law \& Business Press.

Chen, G. Z., \& Xu, J. C. (2002). Criminal Procedure Jurisprudence. China University of Political Science and Law Press.

Chen, G., Liu, X., \& Xin, Q. Q. (2015). Credit Discrimination, Financial Development and Private-Owned Enterprises' Bank Loan Term Structure. Accounting Research, 4, 40-46.

Chen, L., \& Wang, H. (2013). Family Involvement, Political Ties and Institutional Environment-The Case of Chinese Private Enterprises. Management World, 10, 130-141.

Chen, R. H. (2020a). Basic Issues of Corporate Compliance. China Law Review, 1, 178-196.

Chen, R. H. (2020b). The Compliance Incentive Model of Criminal Procedure. China Legal Science, 6, 225-244.

Chinese Entrepreneurial Crime Prevention Research Center, B. N. U. (2019). Entrepreneurial Criminal Risk Analysis Report (2014-2018). Journal of Henan Police College, 4, 19-68.

Decisions of the Federal Constitutional Court 1, 14 (52).

Decisions of the Federal Constitutional Court 103, 310 (318).

Decisions of the Federal Constitutional Court 108, 52 (68).

Decisions of the Federal Constitutional Court 45, 187 (260).

Decisions of the Federal Constitutional Court 90, 96 (140).

Fu, Y. J. (2011). Causes and Countermeasures of State-Owned Asset Loss. Enterprise Research, 20, 12.

Gu, Y. Z., \& Li, C. (2013). The Understanding and Application of the Post-Arrest Detention Necessity Review System. Journal of National Prosecutors College, 1, 74-82.

Guo, J. H. (2012). Corporate Donation in China: Voluntary or Requested? Evidence from Listed Companies. Journal of Finance and Economics, 8, 49-59.

Hart, H. L. A. (1968). Punishment and Responsibility. Oxford University Press.

He, X. G., Zhang, Y. F., Lian, Y. L., \& Lv, F. F. (2013). Political Ties and Firm Value-An Empirical Study in China. China Industrial Economics, 1, 103-115.

Kindhäuser, U., \& Zimmermann. (2020). Criminal Law General Part (9th ed.). Nomos Press.

Li, B. C. (2018). The Improvement of the Leniency Mechanism of Plea and Punishment: the Unfolding of Corporate Crime Perspective. Law Review, 3, 111-121.

Li, B. Y. (2006a). Consideration on Equal Protection for Non-State-Owned Economic. People's Procuratorial Semimonthly, 12, 13.

Li, L. Y. (2020a, October 28). Criminal Law's Protection and Restrictions for Private Enterprises. Procuratorial Daily.

Li, X. H. (2006b). Criminal Law Should Protect the Non-State-Owned Economic Equally. People's Procuratorial Semimonthly, 23, 12.

Li, Y. H. (2020b). Criminal Procedure Incentives for Corporate Compliance in China. Journal of Comparative Law, 1, 19-33.

Li, Y. S., \& Ye, J. (2012). An Outline of Equal Protection in Criminal Law for State-owned and Private Enterprises. Journal of Economic Research, 9, 86-90.

Lin, S. T. (1998). General Theory of Criminal Law (6th ed. Vol. 2). Sanmin Press.

Liu, S. J. (2021). Possibilities and Limits for the Localization of the Corporate Compliance Non-Prosecution System. Journal of Law, 1, 51-65.

Liu, Y. (2017). Analysis of the Causes of State-owned Asset Loss and Countermeasures to 
Address It from the Clearance of Assets. Management Information of China, 3, 113-115.

Lou, L. B. (2020). Procurational Organs' Roles in Preventing and Resolving Private Enterprises' Legal Risk. Journal of Guizhou Police College, 3, 45-50.

Lu, Q. Z. (2020). Research on the Problem of Compliance and Criminal Risk Prevention in the Private Enterprise. Legal Forum, 4, 127-137.

Luo, C. P. (2007). A Comparative Study of Human Rights Protection in Chinese and Swiss Criminal Law. Social People's Press.

Ma, M. L. (2020). Corporate Compliance as a Mean of Crime Governance. Tribune of Political Science and Law, 3, 168-181.

Maunz, Dürig, \& Kirchhof (2020). Commence of Constitutional Law (Art. 3 Para. 1 marginal No. 88-92). C. H. Beck Press.

Mei, C. Q., \& Zhang, Y. Q. (2014). Predicament and Outlet on the Crime of Entrepreneurs of Private Enterprises. Journal of Henan Police College, 5, 40-46.

Osterloh, \& Nußberger. (2020). Sachs Constitutional Law (Art. 3 Marginal No. 1). C. H. Beck Press.

Petchum. (1990). The Ethics of Philosophy. Chinese Social Science Press.

Qiu, X. L. (1999). The Unification of the Principle of Allocation of Punishment. Social Science of China, 6, 32-45.

Radtke. (2020). Munich Commentary on the German Criminal Code 9 (4th ed.). Preliminary Remarks on Article No. 38, C. H. Beck Press.

Rawls, J. (1971). A Theory of Justice (Original ed.). Belknap Press.

Supreme People's Procuratorate, People's Republic of China (2016). About People's Procuratorate Implementing the Examination of the Necessity of Custodial Cases (for Trial Implementation). Article No. 14.

Supreme People's Procuratorate, People's Republic of China (2021). Procuratorial Organs Should Serve as "Maternal Uncle" to Ensure the Healthy Development of the Private Economy. Net of Supreme People's Procuratorate of People's Republic of China. https://www.spp.gov.cn/zdgz/202103/t20210303_510432.shtml

Tian, H. J. (2020). Rethinking on Criminal Compliance. Journal of Peking University (Philosophy and Social Science), 2, 119-130.

Wang, F. J. (2019). Reasons and Countermeasures of State-Owned Assets Loss. Financial World, 18, 14-15.

Xie, X. J. (2016). The Research on Pratice Effect about the Review of the Necessity of Custody. The Jurist, 2, 136-145.

Xiong, Q. H. (2019). Some Suggestions for Strengthening the Protection of Private Entrepreneurs' Personal Property Security in Criminal Procedure Law. Journal of Law Application, 14, 9-15.

Yang, Y. G. (2008). The Impact of International Human Rights Law on China's Criminal Justice Reform. China Legal Press.

Yin, J. F., \& Liu, X. D. (2018). Multi-Dimension Perspectives on the Criminal Law Protection for Private Company Equality. Journal of Guizhou University for Nationalities (Philosophy and Social Sciences Edition), 1, 178-180.

Yu, M. G., \& Pan, H. B. (2008). The Relations between Politics, Institutional Environment and Private Enterprises' Bank Loans. World of Management, 8, 9-21.

Yu, W. Q. (2010). The Theory of Equality in Criminal Procedures. Ph.D. Thesis, South- 
west University of Political Science and Law.

Yuan, B. (2018). The Judicial Path of Non-Criminalization and Its Expanding with the Criminal Protection of Property Right in Private Enterprises. Journal of Law Application, 12, 13-18.

Zhang, W. X. (1996). A Study of the Twentieth Century Western Approach to Legal Philosophical Thought. Law Press.

Zhang, Y. H. (2014). The Current Situation, Hazards and Governance Stance of Corruption Crimes of Private Entrepreneurs. Journal of Henan University (Social Science), 6, 73-77.

Zhang, Y. P. (2015). The Path to Perfection of the Post-Arrest Detention Necessity System. Law Science, 1, 151-159.

Zhang, Z. T. (2019). The Volatility and Regression of Legislative Purpose on the System of Lenient Punishment for Admission of Guilt and Acceptance of Punishment. Law Science Magazine, 10, 1-13.

Zhang, Z. T. (2020). To Standardize System Establishment of Criminal Case Filing against Private Entrepreneur. Law Science, 9, 153-165.

Zhao, B. Z., \& Zuo, J. W. (2017). Three Major Issues of Equal Protection of Private Economy in Criminal Law. Jingyue Journal, 4, 5-13.

Zhao, H. (2020a). A Study on the Leniency of Guilt-Related Enterprises Pleading Guilty to Punishment. Law Science, 4, 122-134.

Zhao, X. L. (2020b). An Important Issue Involving the Protection of the Development of Private Enterprises. Economic Herald, 10, 45-49.

Zhou, Z. J. (2019). Systematic Thought on Equal Protection of Criminal Law for Private Economy. Journal of Political Science and Law, 1, 126-136. 